\title{
ANPET \\ associação nacional de pesquisa e ensino em transportes
}

\section{Diretor Presidente}

Prof. José Eugenio Leal

Secretário Executivo

Prof. Ronaldo Balassiano

Diretor Científico

Profa. Liedi L. Bariani Bernucci

Diretor de Eventos

Profa. Helena Beatriz Bettella Cybis

Diretor de Publicações Científicas

Prof. José Reynaldo Anselmo Setti

Diretor de Relações Institucionais

Waltércio Zanvettor

Diretor de Divulgação

Prof. Joaquim José Guilherme de Aragão

Secretaria:

ANPET - Caixa Postal 68512

21945-970 - Rio de Janeiro, RJ, Brasil

Tel/Fax: (0xx21) 2562-8727 